\title{
On Modern Technologies of Citizens' Participation in Decision Formulation in the Sphere of Education
}

\author{
Vasiliy V. Burov ${ }^{\text {**, }}$ \\ Roman V. Parfenov and Igor M. Remorenko ${ }^{\mathrm{b}}$ \\ ${ }^{a}$ WikiVote \\ 1/9 Maly Kiselny lane, Moscow, 107031, Russia \\ ${ }^{b}$ Moscow City Teachers' Training University \\ 4, 2-nd Selskokhozyastvenny proezd, Moscow, 129226, Russia
}

Received 12.08.2014, received in revised form 25.09.2014, accepted 24.11.2014

An interesting feature of the majority of research in the field of state-public management education is the assumption that public participation in the management of education necessarily involves the creation and operation of certain organizational structures. It seems to us, in addition merit and procedures of management, the very nature of managerial decision making. If we take into account the development of interactive information technologies, opportunities for involving citizens in the design of management decisions becomes much more. It is reasonable to raise the question about the possibility of a special adaptation of the practice of managerial solutions to the peculiarities of the functioning of an open information field. To some extent, this issue is discussed in the framework of crowdsourcing technologies to enable a new level to consider public-public administration as a whole.

Keywords: rowdsourcing, management decisions, State and public administration, work with community initiatives.

Research area: pedagogy, psychology.

The position on state-and-public nature of education management in the Russian Federation was first registered in educational legislation in 1992 when the RF Law "On Education" was adopted. Without mentioning the mechanisms of these legislative provisions in details, the law, however, set the basis for the emergence of a set of new management practices in the educational system. Recent researches allow us to talk about a developing pattern of management which ensures its stateand-public character.

Among such researches are those by V.I. Bochkarev on school self-government and general conceptual approaches to state-andpublic management of education (Bochkarev 1998, 2003), T.A. Stepanova on attracting the society to the mechanisms of evaluation of education quality (Stepanova 2003), E.V. Pereslavtseva on separation of the levels

(C) Siberian Federal University. All rights reserved

* Corresponding author E-mail address: ni.minakova@gmail.com 
of education management and importance to observe the educational legislation (Pereslavtseva 2006), A.A. Sedel'nikov on public organizations' participation in ensuring of a state-and-public character of education management (Sedel'nikov 2011), E.N. Shimutina on public managers' training for their work in school self-government bodies (Shimutina 2012), T.V. Saenko on the stages of the formation of state-and-public education management on the municipal level (Saenko 2009), A.I. Adamskii on an institutional registration of sociopedagogical movements (Adamskii 2003). A detailed historical analysis of the formation of state-and-public education management in the Russian Federation is given in N.M. Fedorova's dissertation research (Fedorova 2010).

The assumption of the fact, that public participation in education management necessarily involves formation and functioning of certain organizational structures such as guardian councils and governing boards, commissions on evaluation of education quality with public experts' participation, school selfgovernment bodies, various coordination structures ensuring interaction between state and public organizations, is an interesting distinctive feature of most researches in the sphere of state-and-public education management. It seems to us that management procedures and nature of managerial decision making proper are also worth paying attention to. Their initial preparation, the citizens' involvement in the discussion of managerial decision making projects, working out of general and uncoordinated positions, search for consensus, verification of the decisions made in practice, and their correction can be viewed as a specific object of the research. The process of engaging the society in routine and seemingly very private management procedures can not only improve the quality of preparation of these decisions but also ensure the necessary number of supporters of these decisions and their subsequent implementation. This enables to ensure a high level of decision making when implementing innovative practices (Patarakin, Iarmakhov, Burov 2012).

At the same time engagement of the society in making managerial decisions shouldn't be considered a good wish to the administrative education authorities' activities only. It's natural that modern opportunities of information and communication technologies, availability of the education management bodies' sites, and special resources for the discussion of administrative documents can become a good tool of the governing bodies' information transparency. However, the information transparency by itself should be considered only as a necessary condition of state-and-public education management (Val'dman 2010).

Posting of documents in the open informational space does not guarantee the public participation in their discussion and revision due to the following facts:

- These documents are, as a rule, written in sophisticated formal language which has been formed within the decades of the administrative management system and complies with the general regulations of administrative work;

- The documents by themselves do not set the context of their adoption, original orders, discussions and conclusions; they contain only defined norms, logically related to other documents which are not presented to the participants of public discussions;

- The nature of the interaction of the participants of an open information field more likely presupposes the discussion of fragmentary simple abstracts rather than extensive complex documents. 
Nevertheless, if we take into account the development of interactive information technologies, we can state that the opportunities for engagement of the public in managerial decisions design are getting significantly numerous. It is reasonable to put a question of a special adaptation of the practice of managerial decisions design for the peculiarities of an open information field's functioning. To some extent this issue is discussed within the framework of crowd sourcing technology which enables to consider state-and-public management on the whole on a new level. A number of authors convincingly show the advantages of crowd sourcing over conventional expert systems of managerial decisions preparation (Howe 2012; Noveck 2012; Surowiecki 2007). The same issues are viewed upon by the Russian applied researches (Burov, Patarakin, Yarmakhov 2011, 2012). Also there have been recent domestic theoretical researches stating the prospects of using crowd sourcing in the state administration practice (Dzhegutanov 2012).

It is important to note that a certain number of crowd sourcing projects in the field of lawmaking have been implemented in Russia by the present. An overview of these projects and methodologies is given in R.V. Parfenov's research (Parfenov 2013).

Analyzing the works mentioned, we can single out the following additional opportunities and characteristic features this technology provides for taking qualitative managerial decisions:

- A considerable number of the participants, who expertise the projects of managerial decisions, make such expertise occasionally more objective than if it had been made by a narrow circle of qualified experts.

- Interaction of the participants of the managerial decisions discussion encourages them to specify the managerial decisions content, form new ideas and mechanisms of their implementation.

- In contrast to other participants more active participants of the discussion have weightier judgments. It makes it possible to regard their opinion as more significant and thus stimulate the other participants' activity level.

- Crowd sourcing helps to maintain high motivation and engage the participants of the discussion in a subsequent activity in accordance with the managerial decisions designed.

Traditional mechanisms of taking managerial decisions do not have such opportunities. And taking into account a considerable scale of the education system, it should be assumed that the use of such technologies in education can turn out to be very promising.

A joint cooperation of WikiVote company and Moscow State Pedagogical University in organization of the discussion of the issue that an essay should be reintroduced to school practice as some new procedure of the senior (grades 1011) students' attestation. At that it is important to emphasize that this project was not our first project to engage the public in managerial decision making.

Prior to this we implemented the project on public discussion of "On Education in the Russian Federation" draft law. This project started in July 28, 2011, lasted till January 10, 2013 and involved 5876 experts who wrote 458 author's versions of the draft law's norms (Parfenov 2013; Patarakin, Yarmakhov, Burov 2012).

Basing on the mentioned above practice of the project work, it can be told about a developing pilot methodology of organizing public discussion and collective elaboration of managerial decisions. 
This methodology can be presented as a set of subsequent steps, combined in the several stages described below.

\section{Stage 0. Emergence of public initiative}

The process of the initiative emergence is not currently covered by the methodology under consideration as this methodology regards the initial version of the public initiative to be input data. Some resonance order of the country's leaders, the government's or agency's proposal, idea accepted by the public group can be viewed as the initiative. The principal aspect here is availability of wide public resonance towards the formulated proposals. The more uncertain, incomplete and problematic the wording seems to be, the more probable it is to arouse the public opinion and engage nonindifferent citizens in the discussion of the issue.

At that we do not talk about the citizens' professional membership. It should be assumed that the problems of education are mostly discussed by those who are employed in the sphere of education. However, taking into account a principal fuzziness of the education boundaries it seems to us that in our case it is much more important to rely on people, able to air interesting proposals, wishes, critical objections or new ideas than to translate some hard-line professional attitude.

In the long term online organization of this stage, and namely of an initiative generation from some complex of relatively random public opinions, seems possible.

\section{Stage 1. Launch of public consultations on the initiative}

The methodology implies that the initiative by itself is issued in the form of some initial conceptual document and based on the support of some community, suggesting a starting conception for further development of public consultations.

Preparation of such conceptual document in each certain case is individual. This process depends on the content of the initiative, the way it is formulated, the volume and the degree of specification.

In case of reintroducing a final essay the preparation was the following: They developed a document with the enumeration of stages the essay to be reintroduced, gave a short but capacious description of these changes and later posted on sochinenie.wikivote.ru site. As the initiative was originally targeted at the pupils' coping with the "philology" educational field at least, the developers of the original conception were outstanding teachers, scholars and practitioners (the authors' teams). Availability of such a team further resulted in the trust of the participants of the discussion to the suggested conception. It differs from the situation when its authors were a group of officials.

From the moment the initiative is posted on the site it is revised by the open community. Anonymous users are not allowed to this work, their registration on the project's site is obligatory for everybody. A fundamentally important point here is to inform the community about the tasks of the stage the right way and competently organize the citizens' involvement. Teachers, representatives of the parent community, other concerned citizens are invited to the discussion. To do this the bloggers, journalists and the authors themselves post corresponding invitations in such social networks as Twitter, Facebook, VKontakte (ВКонтакте), LiveJournal.

The community is assigned the following tasks:

1. To evaluate the wordings of the public initiative. It is achieved by realization of the tools of the description of problems of certain conceptual provisions as well as of the collection 
of proposals on the identified problems on the site. Conceptual provisions are divided into separate blocks, convenient and clear for the discussion and commentaries.

2. To suggest own alternative conceptions on the order of reintroduction of essay to school practice. Within the framework of the revision of the reintroduction of a final essay conception the team of authors, who worked out the original variant of the conception, was sent the alternative conceptions which were posted in a separate block of the site. In the future the possibility of a separate block in similar projects can be considered. The experts can post the alternative variants of realization of initially stated public initiative on the site themselves.

3. To compare and argumentatively evaluate the original wording of the conception of reintroducing the essay and the proposed alternative conceptions. To be posted as the alternative conceptions these conceptions can be subject to prior evaluation and revision by the organizers of the discussion. This will make it possible to bring all these proposals into the formats comparable with one another.
The site provides the possibility to formulate pros and cons of each alternative conception.

The results of this stage are:

1. A comprehensive evaluation of the original conception of the initiative implementation, including a complex evaluation of risks and possible ways of their minimization.

2. Possible alternative conceptions of the initiative implementation.

3. A comparative analysis of the alternatives.

The work at this stage can be presented in the form of the scheme (Fig. 1).

\section{Stage 2: Working out \\ of an integrative variant \\ of the initiative implementation (offline)}

The development of an integrative variant of the initiative implementation is carried out without the use of Internet resources in the framework of the activity of the working group with experts among whom there can be the representatives of the authors, experts on the part of the state regulator, other independent experts.

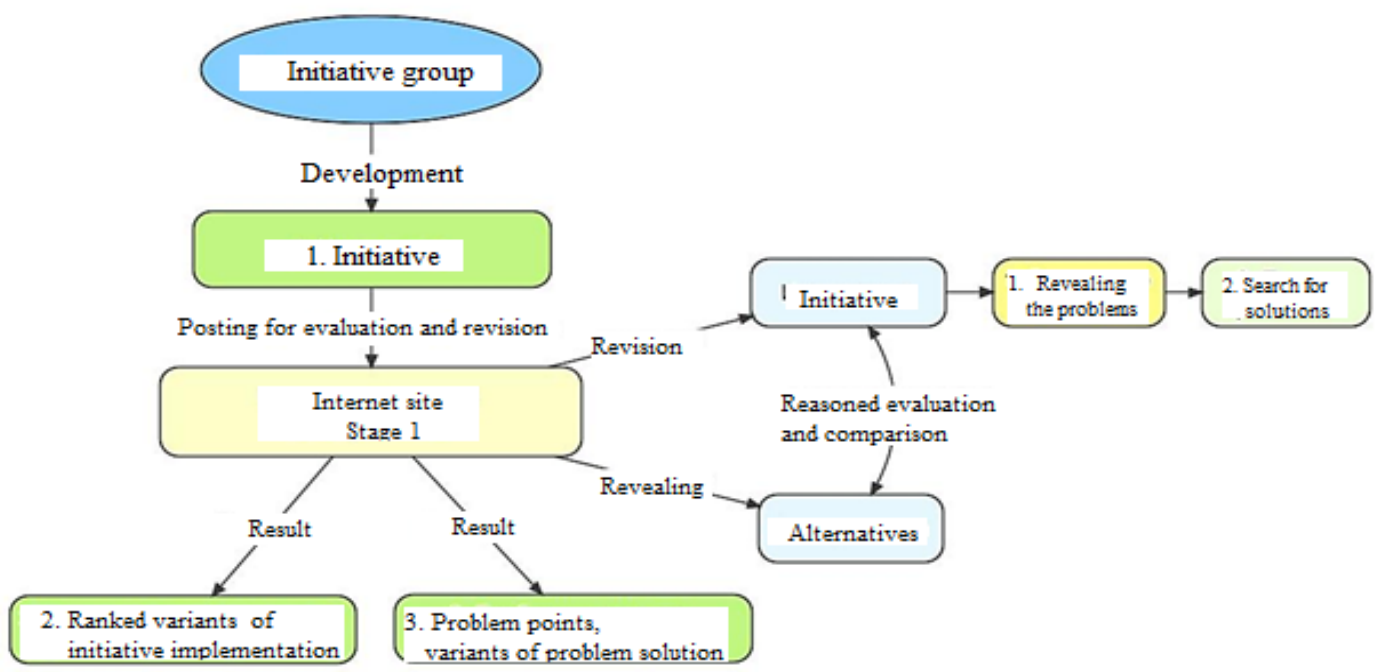

Fig. 1 
The conception of reintroducing a final essay serves an example of working out of an integrative variant of the conception by the working group of the Ministry of Education and Science of the Russian Federation who took into account the results of sochinenie.wikivote.ru site. An integrative conception should contain the description of possible forks significant for implementation of the initial idea. The forks become a part of the general conception on the basis of transformation and considering all the alternatives, suggested at the previous stage. It makes it possible to formulate the task for the community's subsequent discussion. It is formulated as working out of the conception according to the principle of choosing an optimal way within the existing forks.

In the long term perspective to develop such a transforming conception it seems appropriate to consider the issue of forming a special expert team to work out this document. The most active participants of the Internet discussion should be also engaged in this activity.

\section{Stage 3. Revision of a final variant of the initiative}

The conception variant, worked out by the team of experts, is posted on the Internet-site for the variant's further evaluation and revision.
The logic of work with it is patterned according to the following scheme (Fig. 2).

1.The project's expert community can choose one of the forks (alternatives) by voting and introduce it to the text of an integrative variant of the initiative implementation.

Examples of the alternatives of a final conception from sochinenie.wikivote.ru site:

2 possible approaches to the status of the bank of essay topics:

1. Creation of a closed bank of the essay topics for the pupils;

2. Creation of an open bank of the essay topics.

3 possible approaches to the organization of marking the essays:

1. An essay marked by a special independent commission;

2. An essay is marked by a specially invited independent expert who is not a teacher;

3. An essay is marked by a school commission.

3. The participants describe possible problems of implementation of certain provisions of the public initiative.

4. The participants suggest the solutions of the problems revealed.

The results of this stage are the following:

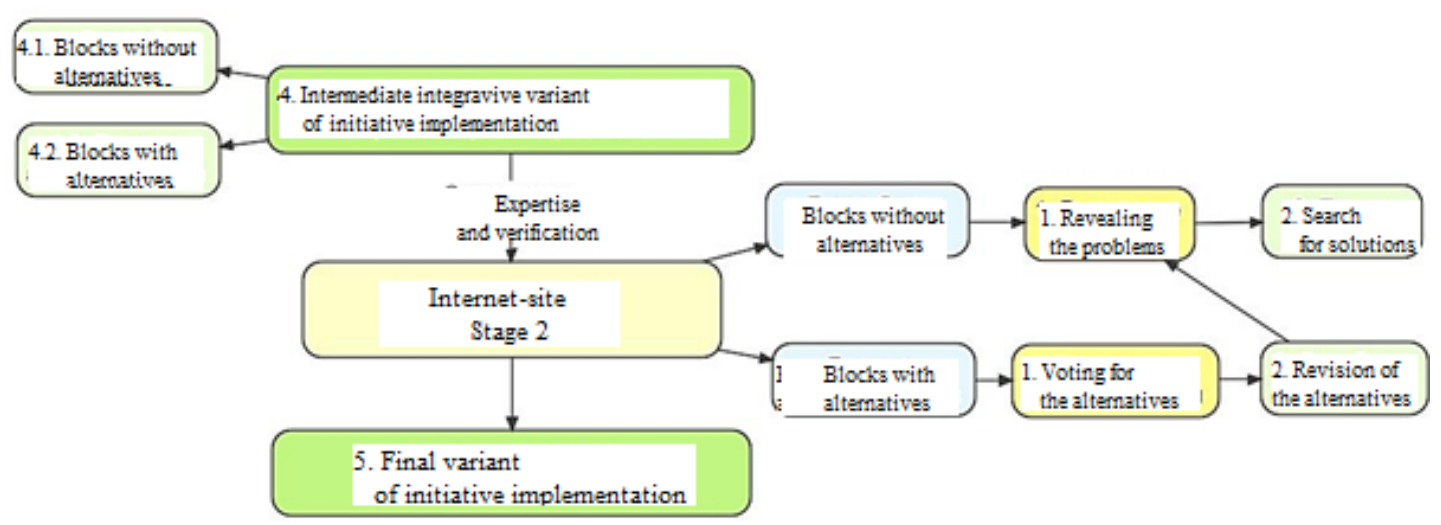

Fig. 2 
- The data about the approved alternatives within the frame of the initiative;

- The problems of the implementation of the initiative's final variant, ranked by their importance;

- The solutions of the revealed problems, ranked by their quality.

\section{Stage 4. Public expertise}

of the normative document

on the basis of the conception developed

Stage 3 results in the formation of a document or several documents that legally register the implementation of a final variant of the public initiative. The type of the document (a law, a decree, an order, etc.) is defined in accordance with the legislation requirements and the level (federal, regional, municipal) the initiative refers to. The legal document mentioned is worked out by the specialists with legal qualification on the basis of a final conception, clearly defined and discussed.

The methodology of a legal document expertise can be illustrated by the following scheme (Fig. 3).

1. The text of a normative legal act is divided into minimal meaningful parts, containing legal norms - articles and paragraphs of the articles.
2. The text, divided this way, is posted on the open Internet-site. Then the work of the public experts (the participants registered in the system) is focused on semantically meaningful parts (articles or regulatory act items, as a rule).

3. The experts can perform the following actions in respect of the paragraphs:

- To specify the appropriateness of the wording oflegal norms of afinal conception of the initiative implementation.

- To add the description of the problems connected with a corresponding paragraph.

- To discuss the problems and rank them according to their importance by voting.

- To propose the solutions of the described problems in the form of own wordings of the corresponding articles and paragraphs.

- To rank author's wordings of the text, which solve the problems of the legal document.

The results of the legal document expertise are the following:

1. The list of problems of the normativelegal act;

2. Solutions of the problems identified;

3. The improved text of the document;

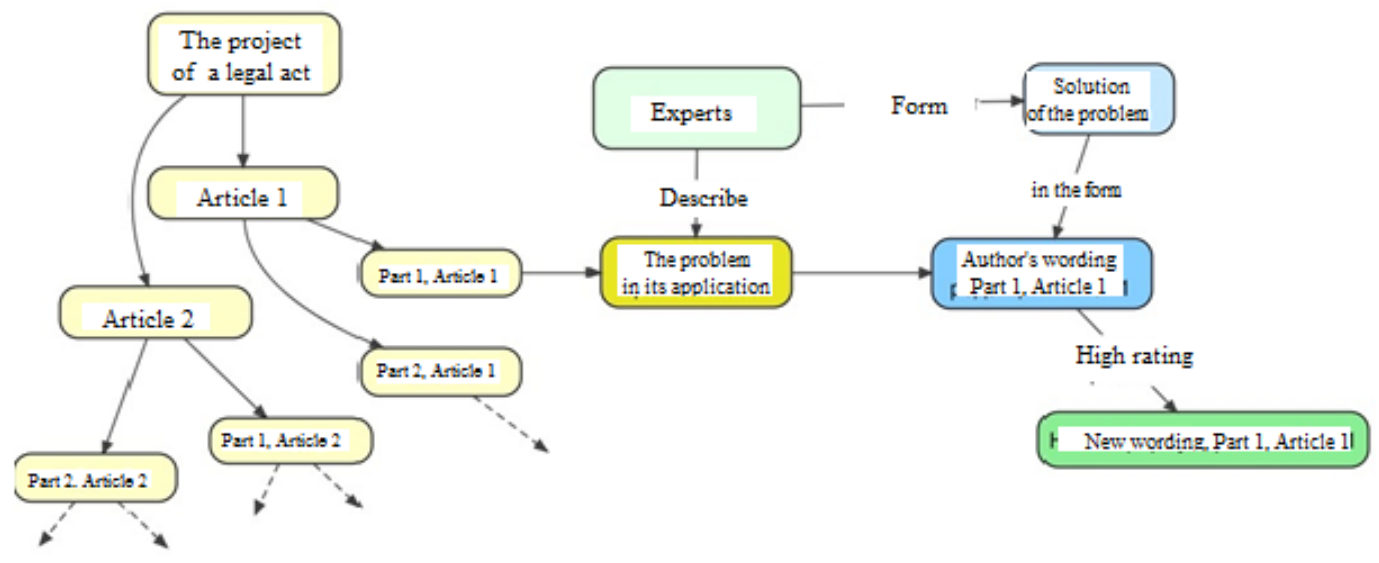

Fig. 3 
4. The team of the most productive working experts, formed from among the participants of the discussion.

As it was mentioned above, in case it becomes possible to form an initial public initiative directly on the Internet space this methodology can be applied as a tool of updating the legal framework. Taking into account the logic of the emergence of such initiatives outside the education system, we can propose the following steps for subsequent testing of decision-making mechanism based on public opinions and proposals:

1. The registered participants suggest the wordings of the problems, requiring solutions, on the open Internet-site. The proposed problems are evaluated by the project's participants according to the degree of their importance and relevance.

2. The project's experts suggest various variants of solution of the problems considered to be the most urgent ones. Problem solutions are also ranked according to the degree of their quality and analysis.

3. The working teams are formed for the most rating pair, which is a "problem - solution" pair. They work out a detailed description of the public initiative on the problem solution. Such working teams can be formed from several parties concerned: the experts from state bodies, public associations; experts from the Internet-site including the authors' of the formulated problem and its solutions and other participants, selected through a special procedure on the Internet-site.

Resulted from all this, the general logic of work with public initiatives can be shown in the scheme below (Fig. 4).

Thus, we assume that the reflection of the work done gives us grounds to talk about the prerequisites for working out of the integral technology ensuring public participation in taking managerial decisions both in the sphere of

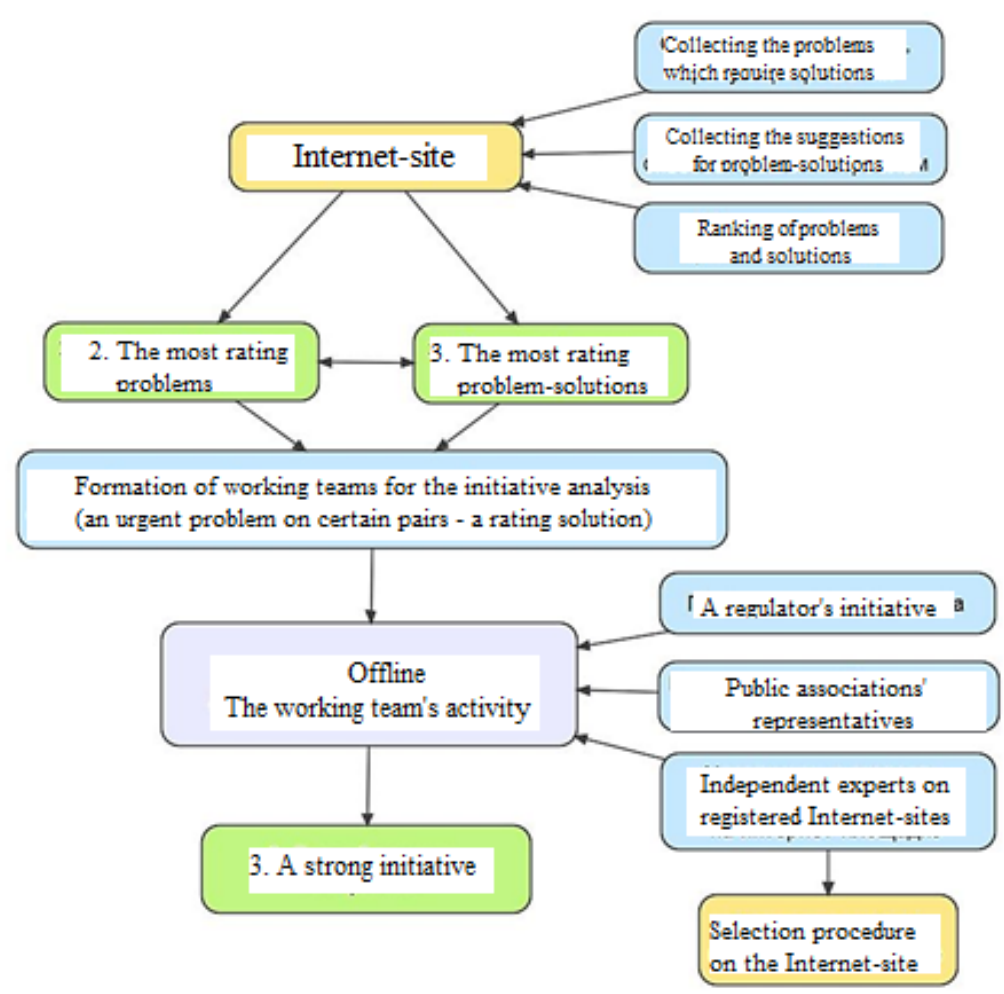

Fig. 4 
education and social sphere in general. In what follows such a technological analysis will make it possible:

- to find acceptable variants of the implementation of public initiatives;

- to build an effective regulatory framework for the implementation of public initiatives;

- to evaluate possible problems on the way of implementing the initiatives;

- to find the ways of possible risks minimization.

It is vital to note that the described techniques enable to fully display the potential and improve the quality of the procedures of the citizens' involvement in rule-making and managerial decision-making, stipulated by Russian legislation:

- Public expertise of regulatory legal acts (the Decree of the RF President No. 167 dated 09.02.2011, the Decree of the RF Government No. 159 dated 22.02.2012, the Decree of the RF Government No. 851 dated 25.08.2012).

- Evaluation of a regulatory impact of regulatory legal acts (the Decree of the RF President No. 601 dated 07.05.2012 No. 601, the Decree of the RF Government No. 1318 dated 17.12.2012);

- Anti-corruption expertise of regulatory legal acts (Federal law No. 172-FZ dated 17.07.2009, the Decree of the RF Government No. 96 dated 26.02.2010);

- Pedagogical expertise of regulatory legal acts (Article 94 of the Federal law "On Education").

The research on the methods of ensuring the joint activity on the improvement of legal texts are not at a stop, and now several directions of their improvement can be singled out:

1. It is reasonable to assume that not all problems formulated on the basis of document articles and paragraphs can be solved by making the author's version of the corresponding rule of law. Based on this, the problem can be divided into:

- The problem of the wording of the rule of law which describes the problem;

- The problem which can be solved by the change of the wording of another norm of the legal act;

- The problem in law enforcement which can be solved by the change of the norms of the legal act;

2. The problem can refer not only to one norm of the legal act, but to several norms. This problem can occur as the norms of the legal act are in their semantic and logical relationships.

3. The work at the norms, determining the main concepts of law, has its certain specific features. It is often the norms which embrace the experts' most active work.

It is reasonable to organize the work at the definition norms so that the experts could not only work at the problems and wordings, but also add new concepts to the list of definitions. Within the frame of the work at definitions, it is possible to create tools by which the experts would be able to build linkages between the main concepts, describing the relations between the part and the whole, intersections of meanings, and creating references to the concepts, which other legal acts contain.

Such relations within the frame of conceptual apparatus can be a great object for visualization that will turn the experts' job simpler and more obvious.

The presented methods together with the description of their meaningful units and bases can specify a certain approbation field in modeling modern technologies of citizens' participation in the working out of managerial decisions both in the system of education and a social sphere in general. 


\section{References}

1. Adamskii A.I. Socio-pedagogic movement in Russian education in 1980-90-ies of the XX century. Ph.D. thesis in Pedagogy. Moscow, 2003. 196 p.

2. Bochkarev V.I. Socio-pedagogic bases of school self-government. Author's abstract of doctoral dissertation in Pedagogy. Moscow, 1998. 42 p.

3. Bochkarev V.I. (2003). Conceptual basis of state-and-public management of general education in Russia. Management in education, 1, 9-18.

4. Burov V.V., Patarakin E.D., Yarmakhov B.B. (2011). Use of crowd sourcing technology in lawmaking activity. Business Informatics, 2, 12-19.

5. Burov V., Patarakin E., Yarmakhov B. A crowdsourcing model for public consultations on draft laws. Proceedings of the 6th International Conference on Theory and Practice of Electronic Governance. New York, USA, 2012, pp. 450-451.

6. Dzhegutanov V.V. Management of a big city's competitiveness. Ph.D. thesis in Economics. Moscow, 2012. $187 \mathrm{p}$.

7. Fedorova N.M. Formation of state-and-public management of school education in Russia. Ph.D. thesis in Pedagogy. St. Petersburg, 2010. 466 p.

8. Howe J. Crowdsourcing: Why the Power of the Crowd is Driving the Future of Business. Moscow, Alpina Publisher, 2012. 288 p.

9. Noveck B. Wiki Government: How Technology Can Make Government Better, Democracy Stronger, and Citizens More Powerful. Moscow, Alpina Publisher, 2012. 292 p.

10. Parfenov R.V. (2013). Crowd sourcing in the sphere of law: Russian practice and prospects. Lawmaking and economics, 7 .

11. Patarakin E.D., Yarmakhov B.B., Burov V.V. (2012). Advance of social innovations by way of public development of documents. Educational Technology \& Society, 517-535.

12. Pereslavtseva E.V. Development of state-and-public management of education in Russia in modern conditions. Ph.D. thesis in Pedagogy. Moscow, 2006. 201 p.

13. Saenko T.V. State-and-public management of municipal system of education. Ph.D. thesis in Pedagogy. Moscow, 2009. 199 p.

14. Sedel'nikov A.A. An integral model of systems of state-and-public management of education. Ph.D. thesis in Pedagogy. Moscow, 2011. 248 p.

15. Shimutina E.N. Board members' training for their work in state-and-public authorities in the system of general education. Ph.D. thesis in Pedagogy. Moscow, 2012. 266 p.

16. Stepanova T.A. State-and-public system of management of the quality of education in the region. Doctoral thesis in Pedagogy. Moscow, 2003. 459 p.

17. Surowiecki J. The wisdom of crowds. Moscow, Vil'iame, 2007. 304 p.

18. Val'dman I.A. Information transparency of general education institution as a condition of its interaction with society. Ph.D. thesis in Pedagogy. Moscow, 2010. 230 p. 


\title{
О современных технологиях участия граждан в подготовке решений в сфере образования
}

\author{
B.B. Буров ${ }^{a}$, \\ Р.В. Парфенов ${ }^{\mathrm{a}}$, И.М. Реморенко ${ }^{\sigma}$ \\ ${ }^{a}$ WikiVote \\ Россия, 107031, Москва, Малый Кисельный пер., 1/9 \\ ${ }^{6}$ Московский городской педагогический университет \\ Россия, 129226, Москва, 2-й Сельскохозяйственный проезд, 4, корп. 1
}

\begin{abstract}
В статье рассматривается новая практика государственно-общественного управления в системе образования. Привлечение общества к принятию управленческих решений становится более эффективным, если использовать современные технологии краудсорсинга. Это позволяет не только скорректировать и сделать более выверенными готовящиеся управленческие решения, но и обеспечить необходимый уровень их общественного принятия. Вовлечение граждан в обсуждение строится по особой технологии, позволяющей оченивать и рейтинговать мнения участников обсуждения, периодически корректировать обсуждаемые материаль, находить новые идеи и соверменствовать иные нормативные документы. Из тысяч участников общественного обсуждения образуются группы экспертов, способных в дальнейшем принимать активное участие в разработке новых управленческих решений. Данная управленческая практика ещё нуждается в своём институциональном оформлении, учитывая, что пока деятельность органов управления в этом направлении носит лишь эпизодический характер. В статье представлена практика организации общественного обсуждения по поводу установления механизма написания школьниками литературных сочинений в 11-м классе.
\end{abstract}

Ключевые слова: краудсорсинг, управленческие решения, государственное и общественное управление, работа с общественными инициативами.

Научная специальность: 13.00.00 - педагогические науки, 19.00.00-nсихологические науки. 